\title{
ПРОФЕСІЙНА ЕТИКА ТА ІІЇ МІСЦЕ У ПІДГОТОВЦІ ФАХІВЦІВ 3 ОБЛІКУ І ОПОДАТКУВАННЯ
}

\author{
Луцьький національний технічний університет
}

\begin{abstract}
У статті розглянуто актуальні питання щодо ролі та значення професійної етики у забезпеченні професійної компетентності при підготовці фахівців з обліку і оподаткування першого (бакалаврського) рівня вищої освіти. Мета дослідження - визначити місце професійної етики у підготовці бакалаврів 3 обліку і оподаткування у закладах вищої освіти та з'ясувати точку зору на значення етичних аспектів у професійній діяльності не лише кваліфікованих фахівців та науковців, а й майбутніх фахівців 3 обліку і оподаткування. Проведене опитування студентів-бакалаврів - випускників 2020 року спеціальності 071 Облік і оподаткування Луцького національного технічного університету 3 метою визначення рівня обізнаності в питаннях професійної етики та розуміння фундаментальних принципів. На основі аналізу їх відповідей на питання анкети виявлено володіння знаннями щодо етики загалом, набутими при вивченні дисциплін загальної підготовки, і розуміння окремих етичних аспектів професійної діяльності, сформованого при вивченні дисциплін професійної підготовки, де розглядались практичні ситуації та їх вирішення з урахуванням дотримання норм професійної етики. 3'ясовано, що майбутні фахівці з обліку і оподаткування усвідомлюють важливість етичної поведінки у професійній діяльності. Обгрунтовано, що необхідні системні знання щодо професійної етики та фундаментальних принципів відповідно до Кодексу етики професійного бухгалтера майбутні фахівці з обліку і оподаткування зможуть отримати при вивченні такої дисципліни, як «Професійна етика». Це дасть можливість забезпечити формування необхідних загальних і професійних компетентностей відповідно до стандарту вищої освіти.

Ключові слова: етика, загальна компетентність, Кодекс етики професійних бухгалтерів, професійна етика, облік, оподаткування, стандарти вищої освіти, фундаментальні приниипи.

\section{PROFESIONAL ETHICS AND ITS PLACE IN THE TRAINING OF SPECIALISTS IN ACCOUNTING AND TAXATION}

\author{
Lutsk National Technical University
}

The article considers topical issues regarding the role and importance of professional ethics in ensuring professional competence in the training of specialists in accounting and taxation of the first (bachelor's) level of higher education. The purpose of the study is to determine the place of professional ethics in the preparation of bachelors in accounting and taxation in higher education and to clarify the point of view on the importance of ethical aspects in the professional activities not only of qualified specialists and scientists, but also future accounting and taxation specialists. A survey of bachelor students, graduates of 2020 in specialty 071 "Accounting and Taxation" at Lutsk National Technical University, has been undertaken in order to determine the level of awareness in matters of professional ethics and understanding of fundamental principles. Based on the analysis of their replies to the questionnaire it was revealed the level of knowledge on ethics in general, acquired doing the courses of general training, and the level of understanding of certain ethical aspects of professional activity, formed during the study of professional courses, within which practical situations and their solutions based on professional ethics were considered. It has been found that future accounting and taxation professionals are aware of the importance of ethical behavior in their professional activities. It was substantiated that future accounting and taxation specialists will be able to obtain the necessary systematic knowledge of professional ethics and fundamental principles in accordance with the Code of Ethics of a Professional Accountant studying such a discipline as «Professional Ethics». This will ensure the formation of the necessary general and professional competencies in accordance with the standard of higher education.

Key words: ethics, general competence, Code of ethics for professional accountants, professional ethics, accounting, taxation, higher education standards, fundamental principles.

Постановка проблеми у загальному вигляді i ï̈ зв'язок 3 важливими науковими та практичними завданнями. Професійна етика є важливою складовою у 
діяльності працівника будь-якого фаху. Не виключенням $є$ професія обліковця, аудитора, працівника податкових і контрольно-ревізійних органів.

Аналіз останніх досліджень, у яких започатковано вирішення проблеми. Науковці приділяють значну увагу вивченню питань формування етичних вимог i дотримання етичних принципів у діяльності фахівців з обліку і оподаткування. Так, етичні аспекти професійної діяльності у сфері бухгалтерського обліку і оподаткування грунтовно викладені, зокрема, у навчальному посібнику авторів Браталан В.П., Гуцаленко Л.В., Здирко Н.Г [2], підручнику автора Герасимової Л. М. [3].

Результати дослідження проблемних питань, пов'язані з етикою у професії бухгалтера, викладені у наукових публікаціях таких авторів: Балазюк О. Ю. [1], Лаврова О. О. [5], Пархоменко С. Ю. [9], Руденко І. І. [5], Федорова В. В. [8], Шульга С. В. [9], Ямборко Г. А. [10] та ін. Вчені, зокрема, розглядають етичні аспекти обліку та аудиту, роль етики і моралі бухгалтера у професійному забезпеченні розвитку обліку, основні положення Кодексу етики в професійній діяльності бухгалтера i аудитора, фундаментальні принципи професійної етики бухгалтера і аудитора, професійну етику бухгалтера в контексті реформування бухгалтерського обліку в Україні, зміст та інституційні аспекти регулювання професійної етики аудитора в умовах євроінтеграції.

Так, Ямборко Г. А. стверджує, що « ... сучасний розвиток бухгалтерського обліку та створення цілісної системи управління неможливий без висококваліфікованих бухгалтерів і аудиторів, які не лише розуміють нові концепції, правила та принципи формування інформації в бухгалтерському обліку, а чітко усвідомлюють потенційні етичні наслідки професійних та управлінських рішень» [10].

Федорова В. В. зазначає, що « ... вкрай вагомою особливістю професійної діяльності працівників бухгалтерської та аудиторської професій $\epsilon$ те, що довіра до результатів та наслідків їх діяльності безпосереднім чином перебуває в залежності від чіткого дотримання етичних вимог до їх професії, основою визначення яких є Кодекс етики МФБ (Міжнародної федерації бухгалтерів). Саме ним встановлено стандарти поведінки обліковців та аудиторів при провадженні ними професійної діяльності» [8].

Балазюк О.Ю. розглядає питання професійної етики бухгалтера в контексті реформування бухгалтерського обліку в Україні [1].

У дослідженні авторів Шульга С. В. і Пархоменко Є. Ю. « ... виокремленні рівні регулювання професійної етики аудитора, встановлено основні нормативні документи, які визначають концептуальні засади професійної етики аудитора. Встановлені основні недоліки нормативно-правової регламентації професійної етики аудиторів, що $є$ перепоною забезпечення захисту суспільних інтересів та поглиблення соціальної відповідальності аудитора» [9].

Руденко I. І., Лаврова О. О. обгрунтовують « ... соціально-важливі аспекти бухгалтерського обліку та етики аудиторської діяльності. Авторами досліджено й обумовлено актуальність існування соціального обліку. Систему бухгалтерського обліку i аудиту проаналізовано як один із елементів забезпечення соціальної відповідальності сучасного бізнесу» [5].

Салова Н. А. визначає завдання професійної етики - « ... вивчити складний процес віддзеркалення професійних відносин у площині моральної свідомості» [6] i акцентує увагу на тому, що « ... відсутність етичної поведінки у спілкуванні між зацікавленими сторонами, недотримання або ігнорування етичних правил призводить до виникнення та процвітання корупції» [6].

Однак, незважаючи на грунтовні дослідження теорії і практики професійної етики бухгалтера, залишаються питання, які вимагають додаткового вивчення.

Цілі статті. Мета нашого дослідження - визначити місце професійної етики у підготовці бакалаврів з обліку і оподаткування у закладах вищої освіти та з'ясувати 
точку зору на значення етичних аспектів у професійній діяльності не лише кваліфікованих фахівців та науковців, а й майбутніх фахівців з обліку і оподаткування.

Виклад основного матеріалу дослідження 3 обгрунтуванням отриманих наукових результатів. Отже, дотримання норм професійної етики $є$ необхідною умовою успішної професійної діяльності і про це знають досвідчені працівники. Але нас зацікавила точка зору студентів-бакалаврів спеціальності 071 Облік і оподаткування.

Навчальний план підготовки бакалаврів спеціальності 071 Облік і оподаткування 2020 року випуску у Луцькому національному технічному університеті не передбачав вивчення окремої дисципліни «Професійна етика», однак окремі питання щодо етики загалом i етичних аспектів професійної діяльності розглядались при вивченні дисциплін як загальної підготовки, так і професійної підготовки.

Зокрема, вивчення дисципліни «Комунікативні процеси у навчанні» у першому навчальному семестрі забезпечило формування у майбутніх фахівців комплексу знань і практичних навичок спілкування, самопрезентації, формування іміджу, виступу в аудиторії, ведення дискусії, вибору ефективного стилю спілкування, протистояння маніпулюванню у комунікації, ділової комунікації, вирішення конфліктних ситуацій.

При вивченні професійних дисциплін, зокрема, таких як «Бухгалтерський облік», «Фінансовий облік», «Управлінський облік», «Облік у банках», «Облік у бюджетних установах», «Судово-бухгалтерська експертиза», «Міжнародні стандарти фінансової звітності», «Контроль і ревізія», «Аудит» та інших розглядаються практичні ситуації та їх вирішення з урахуванням дотримання норм професійної етики.

Нами проведено анкетування студентів-бакалаврів - випускників спеціальності 071 Облік і оподаткування Луцького НТУ з метою визначення рівня обізнаності в питаннях професійної етики та розуміння фундаментальних принципів. Загалом в опитуванні взяли участь 21 студент.

Одностайними були студенти при відповіді на питання «Чи вважаєте Ви, що в будь-якій діяльності, в тому числі й у роботі обліковця, аудитора, податківця, працівника контрольно-ревізійних органів, необхідним є дотримання норм професійної етики?» і всі відповіли ствердно. На інші питання настільки одностайних відповідей не було.

Зокрема, для успішної роботи за обраною спеціальністю, на думку 8 (38\%) опитаних, достатньо знати загальні питання ділової етики, 11 (52\%) опитаних вважають, що необхідна спеціальна підготовка 3 питань професійної етики, і 2 (10\%) опитаних було важко відповісти на це питання. Таким чином, переважна більшість опитаних вважає професійну етику важливим аспектом майбутньої професійної діяльності і зазначає необхідність спеціальної підготовки з питань етичної поведінки у фаховій діяльності.

Коли ж майбутнім фахівцям слід набути практичні навички використання етичних норм? Так, 19 (90\%) опитаних вважають, що фахівцю у сфері обліку і оподаткування слід ознайомитись із вимогами до професії саме в контексті професійної етики під час навчання, 1 із опитаних (5\%) вважає, що це можна зробити в процесі роботи i 1 опитаний (5\%) думає, що це не має значення. Отже, 90\% опитаних усвідомлює необхідність вивчення такої навчальної дисципліни, як «Професійна етика». Це дасть змогу майбутнім фахівцям здобути систематичні теоретичні знання і практичні навички застосування етичних норм у діяльності за фахом.

20 (95\%) опитаних вважають, що їм цікаво було б під час навчання обговорити особливості практичної діяльності і, зокрема, питань професійної етики, з провідними фахівцями-практиками, які мають значний досвід у сфері обліку і оподаткування. 
В Україні та світі діють професійні організації бухгалтерів. Зокрема, з 1977 року діє всесвітня організація бухгалтерів-професіоналів - Міжнародна федерація бухгалтерів (МФБ), створена з метою зміцнення бухгалтерської професії в усьому світі в інтересах суспільства. Міжнародною федерацією бухгалтерів запроваджено міжнародний Кодекс етики професійних бухгалтерів як основу для етичних вимог (кодексу етики, детальних правил, рекомендацій, норм поведінки) до професійних бухгалтерів у кожній країні.

$9(43 \%)$ опитаних знайомі 3 основними положеннями Кодексу етики професійного бухгалтера, 11 (52\%) чули про такий документ, але не знайомі 3 його змістом, і 1 (5\%) не знає про існування такого документа. Отже, менше половини із опитаних знайомі з основними положення Кодексу етики професійного бухгалтера.

У Кодексі етики професійного бухгалтера прописані фундаментальні принципи, яких повинен дотримуватись професійний бухгалтер.

17 (81\%) опитаних вірно зазначили у своїй відповіді, що професійні бухгалтери у своїй професійній діяльності мають дотримуватись таких фундаментальних принципів, як чесність, об'єктивність, конфіденційність, професійна поведінка, професійна компетентність та належна ретельність [4]. Інші опитані відзначили лише окремі із зазначених фундаментальних принципів.

На питання щодо того, якого (чи яких) із фундаментальних принципів професійних бухгалтерів важко дотримуватись фахівцям-практикам, 9 опитаних відзначили професійну компетентність та належну ретельність, 7 відзначили професійну поведінку, 4 - чесність, 3 - конфіденційність, 2 - об'єктивність.

Таким чином, в процесі аналізу відповідей студентів-бакалаврів - випускників спеціальності 071 Облік і оподаткування на питання анкети виявлено певні прогалини у знаннях в питаннях професійної етики. На нашу думку, це пояснюється тим, що у навчальному плані цих студентів не було такої дисципліни, як «Професійна етика», i студенти, відповідно, не отримали необхідних системних знань.

Однак зазначимо, що у 2020 році навчальні плани підготовки бакалаврів за спеціальністю 071 Облік і оподаткування на кафедрі обліку і аудиту Луцького національного технічного університету було модернізовано i до числа дисциплін загальної підготовки включено таку дисципліну, як «Комунікативні процеси та професійна етика». Метою вивчення дисципліни є формування комплексу знань i практичних навичок ділового спілкування, дотримання етичних принципів та норм майбутньої професії бухгалтера, аудитора, ревізора та податкового інспектора.

Це дасть можливість забезпечити формування необхідних загальних i професійних компетентностей відповідно до стандарту вищої освіти за спеціальністю 071 Облік і оподаткування для першого (бакалаврського) рівня вищої освіти, який був затверджений Наказом Міністерства освіти і науки України 19.11.2018 року [7].

Зокрема, це безпосередньо стосується такої загальної компетентності, як ЗК06 (Здатність діяти на основі етичних міркувань (мотивів)) і таких спеціальних (фахових) компетентностей, як СК10 (Здатність застосовувати етичні принципи під час виконання професійних обов'язків) і СК11 (Демонструвати розуміння вимог щодо професійної діяльності, зумовлених необхідністю забезпечення сталого розвитку України, іiі зміцнення як демократичної, соціальної, правової держави) [7].

Налаштовує позитивно той факт, що 14 (67\%) опитаних готові в майбутньому, коли будуть здійснювати практичну діяльність за обраним фахом, зустрітись із студентами і поділитись 3 ними набутим досвідом, зокрема й 3 питань професійної етики.

Висновки. Таким чином, проведене нами опитування студентів-бакалаврів випускників спеціальності 071 Облік і оподаткування Луцького національного 
технічного університету та аналіз їх відповідей на питання анкети дозволив зробити висновок, що майбутні фахівці зазначеної спеціальності усвідомлюють важливість етичної поведінки у професійній діяльності. Відповідно, нами також обгрунтовано необхідність вивчення такої дисципліни, як «Професійна етика» для успішної діяльності за фахом майбутніх обліковців, аудиторів, податківців, працівників контрольно-ревізійних органів.

\section{Список бібліографічного опису:}

1.Балазюк О. Ю. Професійна етика бухгалтера в контексті реформування бухгалтерського обліку в Україні. Економіка та суспільство. 2017. Вип. 10. С. 710-714.

2.Браталан В. П., Гуцаленко Л. В., Здирко Н. Г. Професійна етика. К.: ЦУЛ, 2011. 252 с.

3.Герасимова Л. М. Професійні цінності та етика бухгалтерів та аудиторів. $2014 . \quad$ URL: https://stud.com.ua/59909/etika_ta_estetika/profesiyna_etika_i_tsinnosti_buhgalteriv_i_auditoriv.

4.Кодекс етики професійних бухгалтерів. URL: https://lexinform.com.ua/wp-content/uploads/2018/09/Code-ofEthics_ukr.pdf.

5.Руденко І. І., Лаврова О. О. Етичні аспекти обліку та аудиту. Фінансовий простір. 2013. № 2. С. 113-120.

6.Салова Н. А. Професійна етика аудитора: фундаментальні принципи. Аудитор України. 2015. № 6 (235). С. 14-19.

7.Стандарт вищої освіти за спеціальністю 071 «Облік і оподаткування» для першого (бакалаврського) рівня вищої освіти, затверджений Наказом Міністерства освіти і науки України від 19.11.2018 p. URL: https://mon.gov.ua/storage/app/media/vishcha-osvita/zatverdzeni\%20standarty/2019/05/06/071-oblik-i-opodatkuvannyabakalavr.pdf.

8.Федорова В. В. Кодекс етики в професійній діяльності бухгалтера і аудитора. Суспільство в XXI cmoлітmі: проблеми та перспективи розвитку: Збірник матеріалів Першої науково-практичної інтернет-конференції (4 жовтня 2018 р., м. Київ). К.: КНЕУ, 2018. 86 с. С. 75-77. URL: https://conferencesua.wixsite.com/ibekneu/tezi-dopovidej/sekciya3/fedorova-v-v-kodeks-etiki-v-profesiyniy-diyalnosti-buhgaltera-i-auditora.

9.Шульга С. В., Пархоменко Є. Ю. Професійна етика аудитора в умовах євроінтеграції: зміст та інституційні аспекти регулювання. Ефективна економіка. 2019. № 3. URL: http://www.economy.nayka.com.ua/?op=1\&z=6961.

10. Ямборко Г. А. Професійне забезпечення розвитку обліку: етика і мораль бухгалтера. Облік і фінанси АПК. 2008. №4. С. 184-188.

\section{References:}

1. Balaziuk, O. Iu. (2017) Profesiina etyka bukhhaltera v konteksti reformuvannia bukhhalterskoho obliku v Ukraini [Professional ethics of an accountant in the context of accounting reform in Ukraine]. Ekonomika ta suspilstvo - Economy and Society, 10, 710-714. [in Ukrainian].

2. Bratalan, V. P. \& Hutsalenko, L. V. \& Zdyrko, N. H. (2011) Profesiina etyka [Profesional ethics]. Kiev: Center of educational literature. [in Ukrainian].

3. Herasymova1, L. M. (2014) Profesiini tsinnosti ta etyka bukhhalteriv ta audytoriv [Professional values and ethics of accountants and auditors]. URL: https://stud.com.ua/59909/etika_ta_estetika/profesiyna_etika_i_tsinnosti_buhgalteriv_i_auditoriv. [in Ukrainian].

4. Code of ethics for professional accountants. URL: https://lexinform.com.ua/wp-content/uploads/2018/09/Code-ofEthics_ukr.pdf. [in Ukrainian].

5. Rudenko, I. I. \& Lavrova, O. O. (2013) Etychni aspekty obliku ta audytu [Ethical Aspects Of Accounting And Auditing]. Finansovyi prostir - Financial Space, 2, 113-120. [in Ukrainian].

Salova, N. A. (2015) Profesiina etyka audytora: fundamentalni pryntsypy [Auditor's professional ethics: fundamental principles]. Audytor Ukrainy - Auditor of Ukraine, 6 (235), 14-19. [in Ukrainian].

6. Standart vyshchoi osvity za spetsialnistiu 071 «Oblik i opodatkuvannia» dlia pershoho (bakalavrskoho) rivnia vyshchoi osvity, zatverdzhenyi Nakazom Ministerstva osvity i nauky Ukrainy vid 19.11.2018. URL: https://mon.gov.ua/storage/app/media/vishcha-osvita/zatverdzeni\%20standarty/2019/05/06/071-oblik-i-opodatkuvannyabakalavr.pdf. [in Ukrainian].

7. Fedorova, V. V. (2018) Kodeks etyky v profesiinii diialnosti bukhhaltera i audytora [Code of ethics in the professional activities of accountants and auditors]. Suspilstvo v XXI stolitti: problemy ta perspektyvy rozvytku: Zb. materialiv Pershoi naukovo-praktychnoi internet-konferentsii (4 zhovtnia, m. Kyiv) [Society in the XXI century: problems and prospects of development: Proceedings of the First Scientific and Practical Internet Conference (October 4, Kiev]. K.: KNEU, p. 75-77. URL: $\quad$ https://conferencesua.wixsite.com/ibekneu/tezi-dopovidej/sekciya-3/fedorova-v-v-kodeks-etiki-v-profesiyniydiyalnosti-buhgaltera-i-auditora. [in Ukrainian].

8. Shulha, S. V. \& Parkhomenko, Ye. Yu. (2019) Profesiina etyka audytora v umovakh yevrointehratsii: zmist ta instytutsiini aspekty rehuliuvannia [Professional ethics of auditor in the conditions of european union integration: content and institutional aspects of adjustment]. Efektyvna ekonomika - Effective Economy, 3. URL: http://www.economy.nayka.com.ua/?op=1\&z=6961. [in Ukrainian].

9. Iamborko, H. A. (2008) Profesiine zabezpechennia rozvytku obliku: etyka i moral bukhhalter [Professional support for the development of accounting: ethics and morality of the accountant]. Oblik i finansy APK - Accounting and finance of APC, 4, 184-188. [in Ukrainian].

Дата подання публікації 12.03.2021p. 
